\title{
Copolymerizations of Diallyl Isophthalate and Diallyl Terephthalate with Allyl Benzoate ${ }^{\dagger}$
}

\author{
Akira Matsumoto, Hiromi Sasaki and Masayoshi Orwa \\ Department of Applied Chemistry, Faculty of Engineering, Kansai University; \\ Senriyama, Suita-shi, Osaka, Japan
}

Diallyl isophthalate (DAI) and diallyl terephthalate (DAT) were copolymerized with allyl benzoate $(\mathrm{ABz})$ in bulk at $60^{\circ} \mathrm{C}$, using benzoyl peroxide as an initiator.

In both copolymerization systems the rate of polymerization and the degree of polymerization of the copolymers tended to decrease with an increase in the mole fraction of $\mathrm{ABz}$ in the feed.

In the copolymerization of $\mathrm{DAI}$ with $\mathrm{ABz}$ the residual unsaturation of the copolymer was nearly constant, regardless of the feed molar ratio, while in the copolymerization of DAT with $\mathrm{ABz}$ it tended to increase with increasing the mole fraction of $\mathrm{ABz}$ in the feed.

The apparent monomer reactivity ratios obtained on the basis of the general copolymer composition equation were as follows: $\mathrm{M}_{1}, r_{1}, r_{2}$; DAI, $0.69,1.02 ; \mathrm{DAT}, 0.77,0.89$.

On the other hand, for the copolymerization of DAI with $\mathrm{ABz}$ the following monomer reactivity ratios(MRR) were also estimated on the basis of the cyclocopolymerization mechanişm : $r_{1}=0.77$ (MRR of the uncyclized radical), $r_{c}=0.52$ (MRR of the cyclized radical), $r_{2}=1.00$ (MRR of the $\mathrm{ABz}$ radical).

These results were discussed in connection with the results of the copolymerization of diallyl phthalate with $\mathrm{ABz}^{\text {) }}$.

$\dagger$ Studies of the Polymerization of Diallyl-Compounds. XV.

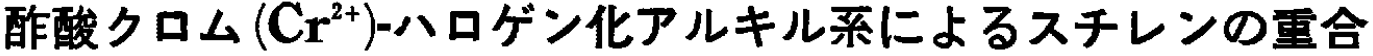

(1971 年 9 月 8 日受 理)

$$
\text { 李武男・箕 浦 有二* }
$$

酢酸クロム $\left(\mathrm{Cr}^{2+}\right)$-ハロダン化フルキル $(\mathrm{RX})$ 系がスチレン $(\mathrm{St})$ の重合をジメチルホルムフミド中で開始するこ とを明らがした。種々の RX を用いて重合を行なった結果, 重合活性はつぎのよ5であった。 $\mathrm{CCl}_{4}>\mathrm{CHCl}_{3}>\mathrm{CH}_{2}$ $\mathrm{Cl}_{2}>\mathrm{CH}_{3} \mathrm{Cl}, \mathrm{CHCl}_{2}-\mathrm{CHCl}_{2}>\mathrm{CH}_{2} \mathrm{Cl}-\mathrm{CH}_{2} \mathrm{Cl}, \mathrm{C}_{6} \mathrm{H}_{5} \mathrm{CH}_{2} \mathrm{Cl}>\mathrm{C}_{6} \mathrm{H}_{6} \mathrm{Cl}, \mathrm{CHI}_{3}>\mathrm{CHBr}_{3}>\mathrm{CHCl}_{3}, \mathrm{CH}_{2} \mathrm{Br}-\mathrm{CH}_{2} \mathrm{Br}>\mathrm{CH}_{2} \mathrm{Cl}_{-} \mathrm{CH}_{2} \mathrm{Cl}_{0}$

$\mathrm{Cr}^{2+}-\mathrm{CHCl}_{\mathrm{s}}$ 系化よる動力学的研究の結果, 重合速度 $\left(R_{\mathrm{p}}\right)$ は $R_{\mathrm{p}} \propto\left[\mathrm{Cr}^{2+}\right]^{1 / 2}\left[\mathrm{CHCl}_{8}\right]^{1 / 2}[\mathrm{St}]$, 見かけの活性化 * ルギーは $11.6 \mathrm{kcal} / \mathrm{mol}$ であった。Stーメタクリル酸メチル (MMA) の共重合による組成曲練㤌, 一般のラシカル重 合に上るものと一致し，重合はラジカル重合であることを明かにした。この開始系 $\left[\mathrm{RX}+\mathrm{Cr}^{2+} \longrightarrow \mathrm{R} \cdot+\mathrm{Cr}^{3+}+\mathrm{Cl}^{-}\right]$ は MMAに対しては重合活性が低く、フクシロニトリル，塩化ビニルに対しては活性を示さかった。

\section{1 緒唓}

金属を含むラジカル重合開始系についての研究が最近活発に行 なわれている。この含金属ラジカル重合開始系の多くは、レドッ クス系に属するが，この系は相手試薬を変えることにより種々の 開始系をつくることができる。その中で系の一方を無機塩とする すのとしては, $\mathrm{Fe}^{2+}-\mathrm{H}_{2} \mathrm{O}_{2}{ }^{1)}, \mathrm{Ce}^{4+}-$ セルロース ${ }^{2)}, \mathrm{Cu}^{2+}-\mathrm{R}-\mathrm{OOH}^{8)}$,

* 大阪市立大学原子基碟研究所, 大阪市住吉区杉本町

1) W.G.Barb, J.H. Baxendale, Trans. Faraday Soc., 47, 462 (1951).

2) G. Mino, S. Kaiserman, E. Rasmussen, J. Polym. Sci., 38, 393(1951).

3) M. E. Müller, ibid., 58, 1009(1962).

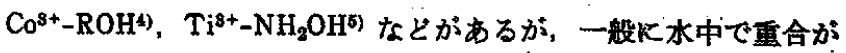

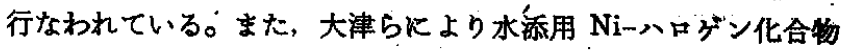

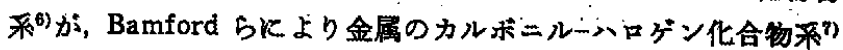
がビニルモノマーのラジカル重合を開始させることが眀らかにさ れている。

著者らは，2 価の醀酸クロム $\left(\mathrm{C}^{2+}\right)$ とハロゲン化アルキル

4）筑浦有二，森 壮六，第 9 回高分子年次大会 (1960) 大阪.

5）加会井敏夫, 岩井作弥, 野口達弥, 高分子化学, 25, 120 (1968).

6) T. Otsu, M. Yamaguchi, Y. Takemura, Y. Kusuki, S. Aoki, J.Polym.Sci., B 5, 679(1967).

7) C. H. Bamford, C. A. Finch, Proc. Roy. Soc., A 268, 553 (1962). 


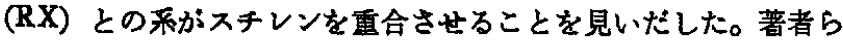
が用いた $\mathrm{Cr}^{2+}$ 塩は いままでに重合にははとんど用いられてい ないが㬊元力がきわめて強く $\left(E_{0}=-0.41 \mathrm{~V}\right)$ ，有機化学におい

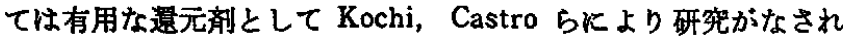
ている8) 11)。たと光ば $\mathrm{Cr}^{2+}$ はつぎに示すように種なの試薬と 反応する。

$$
\begin{gathered}
\mathrm{RX}+2 \mathrm{Cr}^{2+} \stackrel{\mathrm{H}^{+}}{\longrightarrow} \mathrm{RH}+2 \mathrm{Cr}^{3+}+\mathrm{X}^{-} \\
>\mathrm{C}=\mathrm{C}<+2 \mathrm{Cr}^{2+} \stackrel{2 \mathrm{H}^{+}}{\longrightarrow}>\mathrm{CH}-\mathrm{CH}<+2 \mathrm{Cr}^{3+} \\
>\mathrm{C}^{\mathrm{S}} \mathrm{C}<+2 \mathrm{Cr}^{2+} \longrightarrow>\mathrm{C}=\mathrm{C}<+2 \mathrm{Cr}^{3+}+\left(\mathrm{S}^{2-}\right) \\
\mathrm{ROOH}+\mathrm{Cr}^{2+} \longrightarrow \mathrm{RO} \cdot+\mathrm{Cr}^{3+}+\mathrm{OH}^{-}
\end{gathered}
$$

$\mathrm{Cr}^{2+}$ 塩として, $\mathrm{CrSO}_{4}, \mathrm{CrCl}_{2}, \mathrm{Cr}\left(\mathrm{ClO}_{4}\right)_{2}$ などが括す使用さ れているが酸素に対しては非常に不安定である。著者らは，酸素 飞対して他の塩よりる比較的安定な醀酸クロムとハロゲン化アル キルとの系がジィチルホルムアミド中でスチレンを重合させるこ とを見いだしたので報告する。なお，この開始系俚モノマーに対

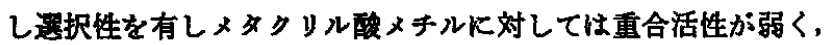

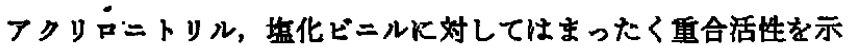
さなかった。

\section{2 実倹}

モノマーのスチレン (St) は 10\% 水酸化ナトリウム水溶液で 洗い，水洗後，塩化カルシウムで晥燥したるのを使用前水水素化 カルシウムを加光減压蒸留し所定留分を用いだ。メダリリル酸メ チル (MMA) は水蒸気蒸留したのち，水酸化ナトリウム水溶夜 で洗い塩化カルシウムで冓燥したるのを空索下減圧蒸留し, 使 用前に水秦化カルシウムを加えらたたび空素下減王蒸留し，庍定 留分を用いた。アクリロニトリル (AN) は水酸化ナトリウム水溶 液, 水で洗ったのち窒素下蒸留し，使用前化水素化カルシウムを 加えらたたび㝧素下蒸留して用いた。塩化ビニル (VC) Kついて は灌硫酸、ソーダ石灰、シリカゲル管を通し 2 回蒸留して用いた。 ハロゲン化アルキル ( $\mathrm{RX})$ については、 ヨードホルム $\left(\mathrm{CHI}_{8}\right)$ は

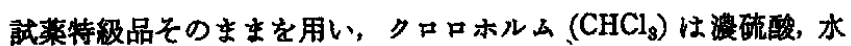
酸化ナトリウム水溶液で洗い炭酸カルシウムで乾燥したすのを窒 秦下蒸留して用いた。他の有機ハロゲン化アルキル化合物につい ては市販品を蒸留して用いた。有機ハロゲン化スズ化合物につい ては，著者の研究室で合成したるのをでンゼンで再結晶して用い た 12) 193。溶媒のジメチルホルムアミド (DMF) 虫水酸化ナトリ ウムを加え迤流したのち蒸留し，使用前に水素化カルシウムを加

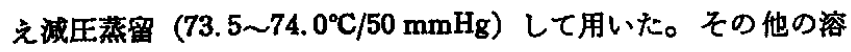
媒隹留により精製して用いた。

2価の酢酸クロム $\left(\mathrm{Cr}^{2+}\right)$ は，アルゴン気流下水溶液中でつぎ の方法により得た ${ }^{14)}$ 。

8) C.E.Castro, W.C. Krag, J.Amer.Chem.Soc., 85, 2768 (1963).

9) C.E.Castro, R.D. Stephens, S. Mojé, ibid., 88, 4964 (1966).

10) J. K. Kochi, D. M. Singleton, L. J. Andrews, Tetrahedron, 24, 3503(1968).

11) J.K.Kochi, Paul E. Mocadlo, J. Org. Chem., 30, 1134 (1965).

12) K. A. Kocheshkov, M.M. Nad, Ber., 66, 1661 (1933).

13) W.P. Neumann et al., Ann.Chem., 663, $11(1963)$.

$$
\mathrm{CrCl}_{3} \frac{\mathrm{Zn}+\mathrm{HCl}}{\underset{\text { 水中 }}{\longrightarrow}} \mathrm{CrCl}_{2} \stackrel{\mathrm{CH}_{2} \mathrm{COONa} \text { 和水溶萑 }}{\longrightarrow} \mathrm{Cr}(\mathrm{OAC})_{2} \downarrow
$$

得られた酢酸クロム結晶を蒸留水、エタノールで洗浄後, 減圧 乾燥した。このものは赤褐色粉末状で，空笑中でもかなり安定 で，取り扱いが他のクロA塩よりも容易であるが，空気中に放㹂 すれば次第に緑色の3 洒のクロム塩になる。 $\mathrm{Cr}^{2+}$ の定量は合成し た瞃酸クロムを硫酸水溶液中で $\mathrm{Fe}^{9+}$ と反応させ，生ずる $\mathrm{Fe}^{3+}$ を の-フェナンスロリンを指示薬とし， $0.1 \mathrm{~N} \mathrm{Na}_{2} \mathrm{~S}_{2} \mathrm{O}_{8}$ で滴定し て行なった。

\section{2 実験方法}

重合は封管重合法を用いた。 $\mathrm{Cr}^{2+}$ の DMF 溶液をアルゴン気 流下で調製し，モノマー， RX，溶媒の順で封管に仕込み， メタ ノールードライアイス中で冷却し，その中へ注射器で $\mathrm{Cr}^{2+}$ 溶液を 所定量加え真空熔封した。佰温槽中で所定時間反応を行ない重合 の停止は反応混合物を大量のメタノール中に加之て行なった。得 られたポリマーは口過隇王䫧嬠し科量した。

粘度剆定は，メタノールーベンゼンで再沈をくり，返して精触し たポリスチレンを Ubbelohde 粘度計を用いて行なった。重合度 は下式で求めた ${ }^{16) 。}$

$$
\log \bar{P}=3.248+1.40 \log [\eta] \quad\left(30^{\circ} \mathrm{C} \text {, ベンゼン中 }\right)
$$

\section{3 結果之孝寀}

\section{$3.1 \mathrm{Cr}^{2+}$ と䆄々の RX による St の直}

$\mathrm{Cr}^{2+}$ 塩による $\mathrm{RX}$ の僄元のさい，中間体としてアルキルラシ

\begin{tabular}{|c|c|c|c|}
\hline $\mathrm{RX}$ & $\begin{array}{l}\text { Time } \\
(\mathrm{hr} .)\end{array}$ & $\begin{array}{c}\text { Temp. } \\
\left({ }^{\circ} \mathrm{C}\right)\end{array}$ & $\begin{array}{l}\text { Yield } \\
(\%)\end{array}$ \\
\hline $\mathrm{CCl}_{4}$ & 1.13 & 30 & 5.9 \\
\hline $\mathrm{CHCl}_{8}$ & 3 & 30 & 6.1 \\
\hline $\mathrm{CH}_{2} \mathrm{Cl}_{2}$ & 11 & 30 & 1.9 \\
\hline $\mathrm{CH}_{3} \mathrm{Cl}$ & 11 & 30 & trace \\
\hline $\mathrm{CHBr}_{3}$ & 2.25 & 30 & 9.0 \\
\hline $\mathrm{CHI}_{\mathbf{8}}$ & 2.25 & 30 & 9.1 \\
\hline $\mathrm{CH}_{2} \mathrm{Cl}-\mathrm{CH}_{2} \mathrm{Cl}$ & 6 & 30 & 1.6 \\
\hline $\mathrm{CHCl}_{2}-\mathrm{CHCl}_{2}$ & 3 & 30 & 4.9 \\
\hline $\mathrm{CH}_{2} \mathrm{Br}-\mathrm{CH}_{2} \mathrm{Br}$ & 4 & 30 & 2.7 \\
\hline$n-\mathrm{C}_{4} \mathrm{H}_{8} \mathrm{Cl}$ & 5 & 70 & 1.5 \\
\hline$s-\mathrm{C}_{4} \mathrm{H}_{9} \mathrm{Cl}$ & 5 & 70 & 1.6 \\
\hline$t-\mathrm{C}_{4} \mathrm{H}_{8} \mathrm{Cl}$ & 5 & 70 & 3.4 \\
\hline $\mathrm{C}_{8} \mathrm{H}_{6} \mathrm{CH}_{2} \mathrm{Cl}$ & 5 & 30 & 3.9 \\
\hline $\mathrm{C}_{6} \mathrm{H}_{5} \mathrm{Cl}$ & 5 & 70 & 1.4 \\
\hline Chloranil & 5 & 30 & 0 \\
\hline $\mathrm{CH}_{3} \mathrm{SnCl}_{3}$ & 5 & 30 & trace \\
\hline$\left(\mathrm{CH}_{3}\right)_{2} \mathrm{SnCl}_{2}$ & 5 & 30 & trace \\
\hline$\left(\mathrm{CH}_{3}\right)_{9} \mathrm{SiCl}$ & 5 & 30 & trace \\
\hline- & 5 & 70 & 1.3 \\
\hline Blank & 6 & 30 & 0 \\
\hline Blank & 5 & 70 & trace \\
\hline
\end{tabular}

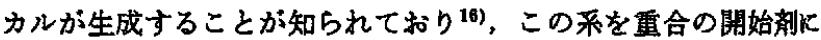

Table 1 Polymerization of styrene initiated by $\mathrm{Cr}^{2+-}$ alkyl halide system in DMF at $30^{\circ} \mathrm{C}$ $[\mathrm{St}]=4.37 \mathrm{~mol} / l . \quad\left[\mathrm{Cr}^{2+}\right]=5.0 \times 10^{-3} \mathrm{~mol} / l$. $[\mathrm{RX}]=5.0 \times 10^{-2} \mathrm{~mol} / l$.

14) "Inorganic Syntheses" McGraw-Hill Book Company, Inc., Vol. 1, p. 122(1939).

15) D. H. Johnson, A.V. Tobolsky, J. Amer. Chem. Soc., 74, 938(1950).

16) J. K. Kochi, D.D.Davis, ibid., 86, 5624(1964). 
用いることを試みた。 $\mathrm{Cr}^{2+}$ と種々の $\mathrm{RX}$ との系により, $30^{\circ} \mathrm{C}$, DMF 中での St の重合を行ない，その結果を表 1 亿示した。そ の結果, $\mathrm{CCl}_{4}, \mathrm{CHCl}_{3}, \mathrm{CHBr}_{3}, \mathrm{CHCl}_{2}-\mathrm{CHCl}_{2}$ などのボリハロダ ソ化合物が大きな活性を有していることがわかった。さらに重 合活性を比較するとハロダン化メタン系では, $\mathrm{CCl}_{4}>\mathrm{CHCl}_{3}>$ $\mathrm{CH}_{2} \mathrm{Cl}_{2}>\mathrm{CH}_{3} \mathrm{Cl}$, ハロダン化ェタン系で柱, $\mathrm{CHCl}_{2}-\mathrm{CHCl}_{2}>\mathrm{CH}_{2} \mathrm{Cl}$ $\mathrm{CH}_{2} \mathrm{Cl}$, さらに芳香核を有する系では， $\mathrm{C}_{6} \mathrm{H}_{5} \mathrm{CH}_{2} \mathrm{Cl}>\mathrm{C}_{6} \mathrm{H}_{5} \mathrm{Cl}$ であ った。また塩化プチルkおいては， $50^{\circ} \mathrm{C} て ゙ 1$ 級，2級， 3 級各 塩化ブキルは重合活性が小であったが, 70Cでの重合では 3 級> 1 級 $>2$ 級の順であった。ハロダンの違いで $\mathrm{CHI}_{8}>\mathrm{CHBr}_{3}>$ $\mathrm{CHCl}_{3}, \mathrm{CH}_{2} \mathrm{Br}-\mathrm{CH}_{2} \mathrm{Br}>\mathrm{CH}_{2} \mathrm{Cl}-\mathrm{CH}_{2} \mathrm{Cl}$ の順であった。これらの結 果は，C-X 結合エネルギーと同し㑯向であり， $\mathrm{Cr}^{2+}$ Kよる $\mathrm{RX}$ の還元の律速段階が C-X 結合の開裂であるという Kochi らの 結果に一致する16)。なおハログンを含を有機金属, $\mathrm{CH}_{8} \mathrm{SnCl}_{3}$, $\left.\left(\mathrm{CH}_{5}\right)_{2} \mathrm{SnCl}_{2} ，\left(\mathrm{CH}_{3}\right)_{3} \mathrm{SnCl} （ \mathrm{CH}_{9}\right)_{3} \mathrm{SiCl}$ Kついて子同様に重合を 行なったか，重合活性は認められなかった。しかし Sn 化合物に ついては $\mathrm{Cr}^{2+}$ はすみやかに酸化され，緑色の $\mathrm{Cr}^{9+}$ になり，そ の速度は、トリクロロ>ジクロロ>モノクロロの順であった。こ のことから；八ロゲンを含む有機金属は重合活性を示さなかった が， $\mathrm{Cr}^{2+}$ とより還元されると考えられる。

\section{2 モ/マー涱度, 開始郕浱度の番合速度に与える影響}

$\mathrm{RX}$ としてクロロホルム $\left(\mathrm{CHCl}_{3}\right)$ を用い, $\mathrm{Cr}^{2+}-\mathrm{CHCl}_{3}$ 系で $30^{\circ} \mathrm{C}, \mathrm{DMF}$ 中 St の重合を行なった。四IK $\mathrm{Cr}^{2+}$ 淟度を変化 させたときの時間-変化率の関係を示した。重合の初期比時間-変 化率曲線がやや权る傾向を示した。重合初速度 $\left(R_{\mathrm{p}}\right)$ は原点での 接線の傾きから求めた。 $R_{\mathrm{p}}$ と $\mathrm{Cr}^{2+}$ 濃度 $\left[\mathrm{Cr}^{2+}\right]$ との関係を図

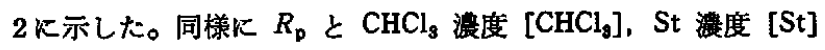
との各関係を図 3，4 亿示した。これらの図から $R_{\mathrm{p}}$ と各濃度と の間につぎの式を得た。

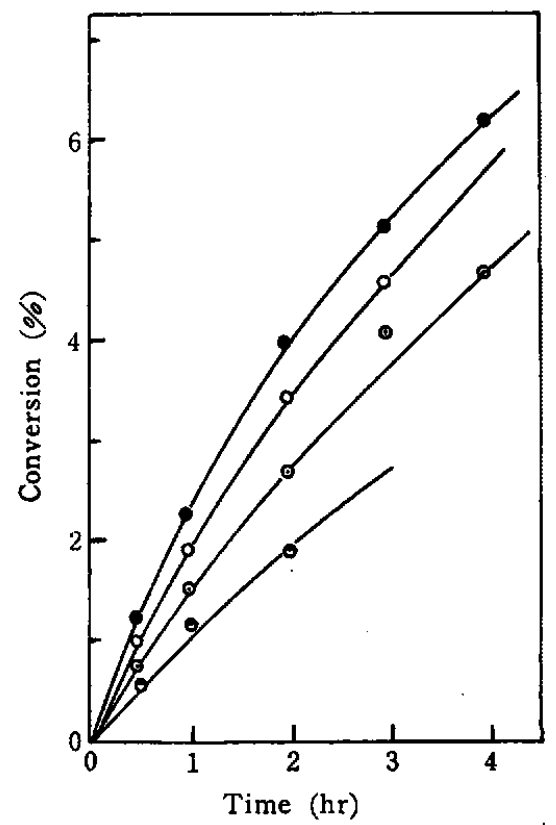

Fig. 1 Time conversion curves of the polymerization of styrene initated by $\mathrm{Cr}^{2+}-\mathrm{CHCl}_{s}$ system in $\mathrm{DMF}$ at $30^{\circ} \mathrm{C}$

$[\mathrm{St}]=3.97 \mathrm{~mol} / l, \quad\left[\mathrm{CHCl}_{8}\right]=4.54 \mathrm{~mol} / l$.

$\left[\mathrm{Cr}^{2+}\right]: O: 6.0 \times 10^{-2} \mathrm{~mol} / l, O: 4.5 \times 10^{-2} \mathrm{~mol} / l$. $\odot: 3.0 \times 10^{-2} \mathrm{~mol} / l, \Theta: 1.5 \times 10^{-2} \mathrm{~mol} / l$.

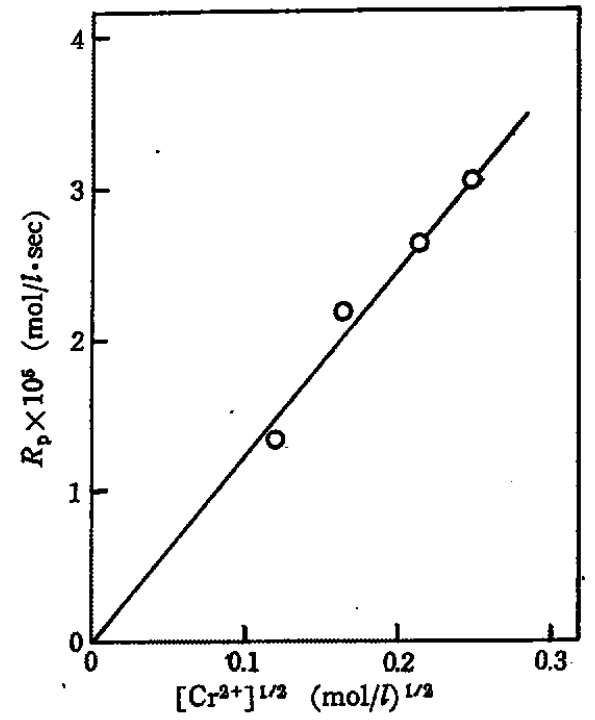

Fig. 2 Effect of the initial concentration of $\mathrm{Cr}^{2+}$ upon the polymerization rate at $30^{\circ} \mathrm{C}$, in $\mathrm{DMF}$.

$[\mathrm{St}]=3.97 \mathrm{~mol} / l, \quad\left[\mathrm{CHCl}_{8}\right]=4.54 \times 10^{-2} \mathrm{~mol} / l$

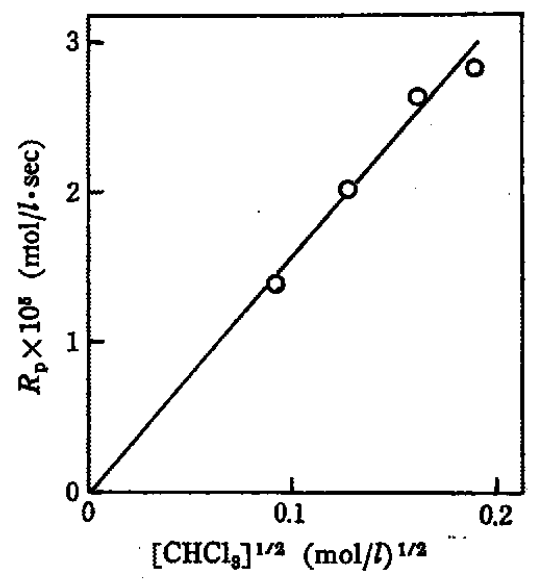

Fig. 3 Effect of the initial concentration of $\mathrm{CHCl}_{3}$ upon the polymerization rate at $30^{\circ} \mathrm{C}$, in $\mathrm{DMF}$.

$[\mathrm{St}]=4.37 \mathrm{~mol} / l, \quad\left[\mathrm{Cr}^{2+}\right]=5.0 \times 10^{-2} \mathrm{~mol} / l$.

$R_{\mathrm{p}} \propto\left[\mathrm{Cr}^{2+}\right]^{1 / 2}\left[\mathrm{CHCl}_{\mathrm{s}}\right]^{1 / 2}[\mathrm{St}]$

、この式は一般にラジカル重合のさい得られる成係であり，成最 ラジカルの 2 分子停止を示するのである。また $\left[\mathrm{Cr}^{2+}\right]$ 変化に上 り得られたボリマーの重合度を表 2 に示した。 $\left[\mathrm{Cr}^{2+}\right]$ が高くなる につれ重合度は減少している。

\section{3 合温度の直合速度に与える影策}

$\mathrm{Cr}^{2+}-\mathrm{CHCl}_{8}$ 系による St の重合において温度を $20,30,40^{\circ} \mathrm{C}$ 変化させて重合を行なった。温度と $R_{\mathrm{p}}$ との関係を图 5 飞示し た。図 5 から重合の見かけの活性化エネルギー $\left(E_{\mathrm{s}}\right)$ は-11.6 $\mathrm{kcal} / \mathrm{mol}$ であった。 $E_{\mathrm{a}}=1 / 2 E_{\mathrm{t}}+E_{\mathrm{p}}-1 / 2 E_{\mathrm{t}} . \quad E_{\mathrm{p}}-1 / 2 E_{\mathrm{t}}=6.5$ $\mathrm{kcal} / \mathrm{mol}$ を用いると ${ }^{17)}$, 開始の活性化エネルギーとして $E_{1}=10.2$ $\mathrm{kcal} / \mathrm{mol}$ が得られた。アレ゙ビスイソブテロニトリル (AIBN) ${ }^{18)}$

17) Kh.S.Bagdasaryan 著, “ラシカル重合の理論”, 井本 棇, 二見 訳, 朝會 (1964) p. 106.

18) V. Van Hook, A. Tobolsky, J. Amer. Chem. Soc., 80. - 


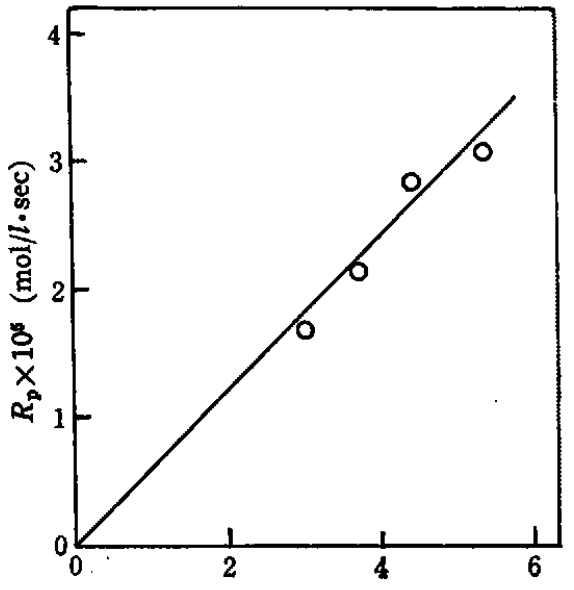

[Styrene] $(\mathrm{mol} / \mathrm{l})$

Fig. 4 Effect of the initial concentration of styrene upon the polymerization rate at $30^{\circ} \mathrm{C}$, in $\mathrm{DMF}$,

$\left[\mathrm{Cr}^{3+}\right]=5.0 \times 10^{-2} \mathrm{~mol} / l, \quad\left[\mathrm{CHCl}_{8}\right]=4.0 \times 10^{-2} \mathrm{~mol} / l$.

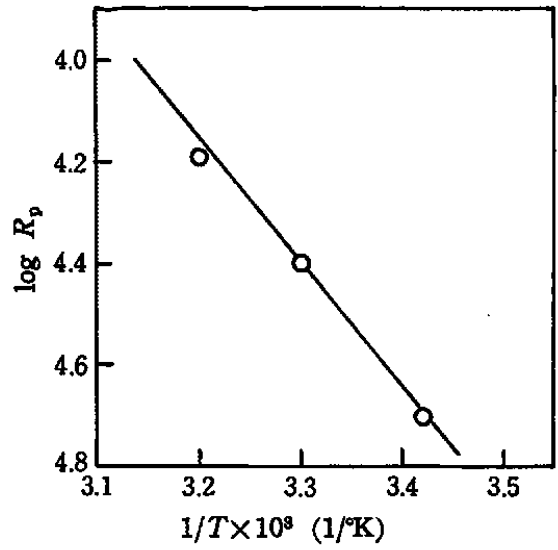

Fig. 5 Arrhenius plot for the polymerization of styrene by $\mathrm{Cr}^{2+}-\mathrm{CHCl}_{3}$ system

$[\mathrm{St}]=4.37 \mathrm{~mol} / l, \quad\left[\mathrm{Cr}^{2+}\right]=4.0 \times 10^{-2} \mathrm{~mol} / l$, $\left[\mathrm{CHCl}_{3}\right]=5.0 \times 10^{-2} \mathrm{~mol} / l$, in $\mathrm{DMF}$.

Table 2 Relationship between $\mathrm{Cr}^{2+}$ concentration and polymerization degree of polystyrene initiated by $\mathrm{Cr}^{2+}-\mathrm{CHCl}_{3}$ system in DMF at $30^{\circ} \mathrm{C}$

$[\mathrm{St}]=3.97 \mathrm{~mol} / l . \quad\left[\mathrm{CHCl}_{8}\right]=4.54 \times 10^{-2} \mathrm{~mol} / l$.

\begin{tabular}{ccccc}
\hline $\begin{array}{c}\mathrm{Cr}^{2+} \\
(\mathrm{mol} / \mathrm{l})\end{array}$ & $6.0 \times 10^{-2}$ & $4.5 \times 10^{-2}$ & $3.0 \times 10^{-2}$ & $1.5 \times 10^{-2}$ \\
$\begin{array}{c}\text { Conversion } \\
(\%)\end{array}$ & 6.5 & 4.7 & 4.6 & 4.0 \\
$\begin{array}{c}\text { Degree, of } \\
\text { polymeri- }\end{array}$ & 77 & 107 & 124 & 129 \\
zation & & & &
\end{tabular}

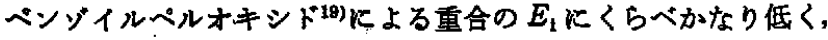
一般のレドックス系による開始の活性化エネルギーに一致してい る。このことから， $\mathrm{Cr}^{2+}-\mathrm{RX}$ 系を用いて低温において重合を行な らことの可能性があると考えられる。

\subsection{St と MMA との共重合}

St と MMA との共重合を, $\mathrm{AIBN}$ 系, $\mathrm{Cr}^{2+}-\mathrm{CHCl}_{3}$ 系, 各 30 , $50^{\circ} \mathrm{C}$, DMF 中で行ない゙,その仕込みモノマー組成とポリマー組

19）文献 17) の p. 40 .
Table 3 Effects of inhibitors on polymerization of styrene initiated by $\mathrm{Cr}^{2+}-\mathrm{CHCl}_{3}$ system in DMF at $30^{\circ} \mathrm{C}$ for $3 . \mathrm{hr}$.

$[\mathrm{St}]=4.37 \mathrm{~mol} / l . \quad\left[\mathrm{Cr}^{2+}\right]=5.0 \times 10^{-2} \mathrm{~mol} / l$. $\left[\mathrm{CHCl}_{3}\right]=5.0 \times 10^{-2} \mathrm{~mol} / l$.

\begin{tabular}{ccc} 
Inhibitor & $\begin{array}{c}\text { Concentration of } \\
\text { the inhibitor } \\
(\mathrm{mol} / l) \times 10^{-2}\end{array}$ & $\begin{array}{c}\text { Yield } \\
(\%)\end{array}$ \\
\hline Hydroquinone & 12.5 & 5.2 \\
Hydroquinone & 10.0 & 5.2 \\
Hydroquinone & 5.0 & 5.1 \\
Hydroquinone & 2.0 & 5.3 \\
Phenyl- $\beta$-naphtylamine & 5.0 & 5.1 \\
2, 6-Di- $t$-butyl- $p$-cresol & 5.0 & 5.1 \\
p-Benzoquinone & 5.0 & 0 \\
picric acid & 5.0 & 0
\end{tabular}

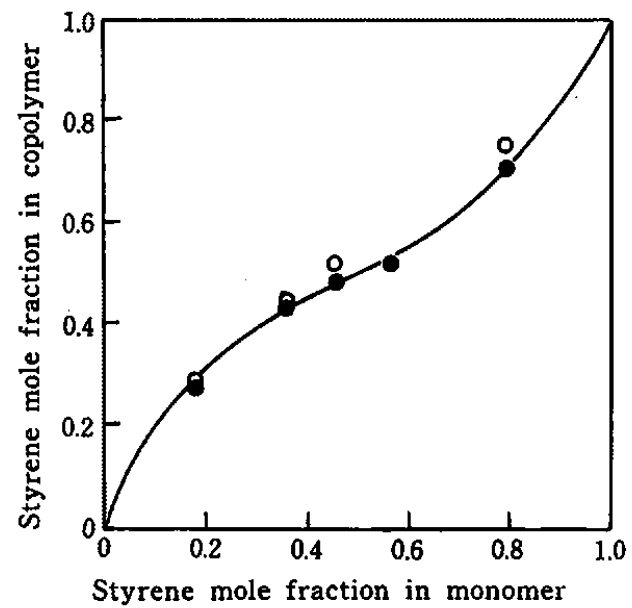

Fig. 6 Composition curve of the MMA-styrene copolymer obtained by $\mathrm{Cr}^{2+}-\mathrm{RX}$ system

: initiated by $\mathrm{Cr}^{2+}-\mathrm{CHCl}_{3}$ system at $30^{\circ} \mathrm{C}$ $\mathrm{O}$ : initiated by $\mathrm{AIBN}$ at $50^{\circ} \mathrm{C}$

$\left[\mathrm{Cr}^{2+}\right]=5.0 \times 10^{-2} \mathrm{~mol} / l, \quad\left[\mathrm{CHCl}_{3}\right]=5.0 \times 10^{-2} \mathrm{~mol} / l$, $[A I B N]=5.0 \times 10^{-2} \mathrm{~mol} / l$, in DMF.

成との関係を図6に示した。温度によりモノマーの反伈性はほと んど関係しないことから， $\mathrm{Cr}^{2+}-\mathrm{CHCl}_{3}$ 系による共重合曲線は AIBN によるものとよく一致し， $r_{1}=0.53 ， r_{2}=0.47$ が得られ， この系がラジカル重合であることを示している。なお MMA 単独 の重合では $\mathrm{Cr}^{2+}-\mathrm{CHCl}_{3}$ 系は低い活性を示した。

\section{5 禁止绪の添加効果}

$\mathrm{Cr}^{2+}-\mathrm{CHCl}_{3}$ 系による St 重台がラジカル重合であることが明 らかにされたが，さらにこの重合系にラジカル重合禁止剤を添加 してみた。その結果を表 3 に示した。がベンジキノン，ピクリン 酸クロラニルは St の重合を完全に禁止したが，ヒドロキノン， フェニルーB-ナフチル アミン，2,6-ジーt-ブチル-p-クレゾールは 停止作用をまったく示さなかった。前者の場合，重合系の色がす みやが変わり重合の禁止作用は成長ラジカルを停止させたのて はなく、これらの禁止郕が強い電子受容性であるため $\mathrm{Cr}^{2+}$ との 反応がさきに起きたためと考えられる。後者の禁止用がまったく 効果を示さなかったことについては明らかでない。

\section{6 溶媒效果}

重合系に二三の溶媒を添加し，DMF との混合溶媒系でそれら の効果を検討した。表 4 に各溶媒系で得られたポリスチレンの収 
Table 4 Solvent effects on polymerization of styrene initiated by $\mathrm{Cr}^{2+}-\mathrm{CHCl}_{3}$ system in $\mathrm{DMF}$ at $30^{\circ} \mathrm{C} *$ polymerization time : $4 \mathrm{hrs}$.

$[\mathrm{St}]=4.37 \mathrm{~mol} / l . \quad\left[\mathrm{Cr}^{2+}\right]=4.0 \times 10^{-2} \mathrm{~mol} / l$.

$\left[\mathrm{CHCl}_{3}\right]=4.0 \times 10^{-2} \mathrm{~mol} / l$.

\begin{tabular}{ccccc} 
Solvent & $\begin{array}{c}\text { Dielectric } \\
\text { constant }\end{array}$ & $\begin{array}{c}\text { Dipole } \\
\text { moment }\end{array}$ & $\begin{array}{c}\text { Yield } \\
(\%)\end{array}$ & $\begin{array}{c}\text { Degree of } \\
\text { the poly- } \\
\text { merization }\end{array}$ \\
\hline DMF & $36.7^{1)}$ & $3.82^{13}$ & 4.5 & 191 \\
DMSO & $48.9^{1)}$ & $4.03^{1)}$ & 5.8 & 179 \\
HMPA & $34^{1)}$ & $4.3 \sim 5.54^{1)}$ & 6.9 & 169 \\
Benzene & $2.27^{2)}$ & $0^{2)}$ & 4.3 & 194
\end{tabular}

* mixed DMF $3 \mathrm{ml}$. and each solvent $2 \mathrm{ml}$.

1) F.M.Aubrg, Bull. Soc.Chim.Fr., 1966, 1945.

2) A.P. Altschuller, J.Phys.Chem., 53, 392(1954).

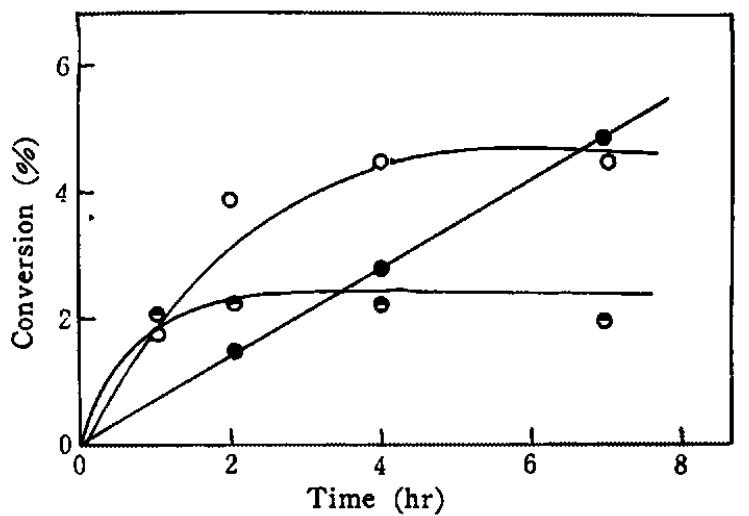

Fig. 7. Time conversion curves of the polymerization of methyl methacrylate initiated by $\mathrm{Cr}^{2+}-\mathrm{CHCl}_{3}$ system

$[\mathrm{MMA}]=4.68 \mathrm{~mol} / l, \quad\left[\mathrm{Cr}^{2+}\right]=4.0 \times 10^{-2} \mathrm{~mol} / l$, $\left[\mathrm{CHCl}_{3}\right]=4.0 \times 10^{-2} \mathrm{~mol} / l$. in DMF Polymerization temperature

$: 0^{\circ} \mathrm{C}, O: 30^{\circ} \mathrm{C}, \theta: 40^{\circ} \mathrm{C}$

量と重合度を示した。へキサメチレンホスホルアミド(HMPA)を 用:た重合系は紫色を示し $\mathrm{Cr}^{2+}$ との錯体形成が考えられる。 HMPA がもっとも収量が离く，重合度はもっとも低い。以下ジ メキルスルホオキシト゚ (DMSO), DMF の順で収壘は低くなり， 重合度は高くなっている。このことから，これら極性溶媒は重合 の開始段階に影製を与えているのではなかららかと考えている。

\section{7 二三のモノマーの更合}

$\mathrm{Cr}^{2+}-\mathrm{CHCl}_{3}$ 系により $\mathrm{St}$ が重合することが明らかにされたが， 他のビニルモノマーについても同様に検討を行なった。MMA K ついては図7に示した。高温 $\left(30 \sim 40^{\circ} \mathrm{C}\right)$ では低重合率で重合が とまってしまう結果が得られまたアクリロニトリル，塩化どニ ルに対しては同じ条件下まったく重合しなかった。これらのこと は $\mathrm{Cr}^{2+}$ が開始反応以外にす関与していることを示しているが， このモノマー選択性に対しては明らかでない。
Table 5 Relationship between conversion and the polymerization degree of polystyrene initiated by $\mathrm{Cr}^{2+}-\mathrm{CHCl}_{\mathrm{g}}$ system in DMF at $30^{\circ} \mathrm{C}$

$[\mathrm{St}]=4.37 \mathrm{~mol} / l . \quad\left[\mathrm{Cr}^{2+}\right]=5.0 \times 10^{-2} \mathrm{~mol} / l$.

$\left[\mathrm{CHCl}_{8}\right]=4.0 \times 10^{-2} \mathrm{~mol} / l$.

$\begin{array}{lcccc}\begin{array}{l}\text { Conversion } \\ (\%)\end{array} & 3.3 & 4.8 & 6.3 & 8.3 \\ \begin{array}{l}\text { Degree of } \\ \text { polymerization }\end{array} & 85 & 91 & 102 & 113\end{array}$

\section{8 正合機構}

$\mathrm{Cr}^{2+}-\mathrm{CHCl}_{3}$ 系による St の重合が $\mathrm{Cr}^{2+}$ による $\mathrm{C}-\mathrm{X}$ 結合の開 裂で生成したラジカルで開始されることが明らかになり，また重 合速度式として通常のラジカル重合で得られる 2 分子侉止の (1) 式（前出）を得た。

$\mathrm{Fe}^{8+}, \mathrm{Cu}^{2+}$ がポリマーラジカルを酸化し重合の禁止都になる ことはよく知られているが，Kochi により $\mathrm{Cr}^{2+}$ はハロゲン化ア ルキルを還元するのみでなく，有機ラジカルをる還元することが 明らかにされている。以上のことを考虑し，つぎに重合素反応を 考えた。

$$
\begin{aligned}
& \text { 開始 } \mathrm{Cr}^{2+}+\mathrm{RX} \stackrel{k_{\mathrm{d}}}{\longrightarrow} \mathrm{R} \cdot+\mathrm{Cr}^{3+}+\mathrm{X}^{-} \\
& \mathrm{R} \cdot+\mathrm{M} \stackrel{\boldsymbol{k}_{\mathrm{i}}}{\longrightarrow} \mathrm{M} \text {. } \\
& \mathrm{R} \cdot+\mathrm{Cr}^{2+} \stackrel{k_{\mathrm{r}}}{\longrightarrow} \text { 生成物 } \\
& \text { 生展 } \mathrm{M} \cdot+\mathrm{M} \stackrel{k_{\mathrm{p}}}{\longrightarrow} \mathrm{M} \text {. } \\
& \text { 停止 } \mathrm{M} \cdot+\mathrm{M} \cdot \stackrel{k_{\mathrm{t}}}{\longrightarrow} \text { ポリマー } \\
& \mathrm{M} \cdot+\mathrm{Cr}^{2+} \stackrel{k^{\prime}}{\longrightarrow} \text { ポyマー }
\end{aligned}
$$

$\mathrm{R} \cdot, \mathrm{M}, \mathrm{M} \cdot, k$ はおのおの一次 カル，素反応速度定数を示す。また（4）式は一次ラジカルの

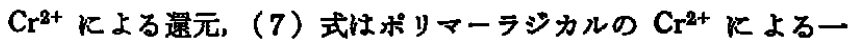
分子停止反応を示す。ここで著者らの行なった重合体件は $\left[\mathrm{Cr}^{2+}\right]$ $\simeq[R X]$ であり，また（2）式の反応が非常に速い迅速開始型と 考えられる。このことは時間変化率曲線がややねていることと 重合度が変化率が高くなるにつれ堌加していることから考えられ る。重合度と変化率との関係を表 5 に示した。以上のことを考虞 すると亲反応（4)，（7）は無視することができ，[M·] に対し 定常状態を仮定すれば通常のラシカル重合と同様に（8）式が监 かれ，実験式（1）と一致した。

$$
R_{\mathrm{p}}=k_{\mathrm{p}}\left(\frac{k_{\mathrm{d}}}{k_{\mathrm{t}}}\right)^{1 / 2}\left[\mathrm{Cr}^{2+}\right]^{1 / 2}[\mathrm{RX}]^{1 / 2}[\mathrm{M}]
$$

$\left[\mathrm{Cr}^{2+}\right] \ll[R X]$ の場合は重合素反応に特別火影繁を与之るとは 考えられず， $\left[\mathrm{Cr}^{2+}\right] \simeq[\mathrm{RX}]$ の場合と同様上考えられるが，しか

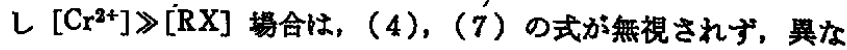
った結果が得られるが，それについては別報で報告する。

\section{Polymerization of Styrene Initiated with Chromous}

\section{Acetate $\left(\mathrm{Cr}^{2+}\right)$-Alkyl Halide System}

Munam LeE and Yuji Minoura

Department of Chemistry, Research Institute for Atomic Energy, Osaka City University; Sugimoto-cho, Sumiyoshi-ku, Osaka-shi, Japan

It was found that styrene was polymerized with chromous acetate $\left(\mathrm{Cr}^{2+}\right)$-alkyl halide(RX) system as an initiator at $30^{\circ} \mathrm{C}$ in dimethylformamide(DMF). 
Polymerization ability for various alkyl halides was in the following order. $\mathrm{CCl}_{4}>\mathrm{CHCl}_{3}>$ $\mathrm{CH}_{2} \mathrm{Cl}_{2}>\mathrm{CH}_{8} \mathrm{Cl} ; \mathrm{CHCl}_{2}-\mathrm{CHCl}_{2}>\mathrm{CH}_{2} \mathrm{Cl}-\mathrm{CH}_{2} \mathrm{Cl} ; \mathrm{C}_{6} \mathrm{H}_{5} \mathrm{CH}_{2} \mathrm{Cl}>\mathrm{C}_{6} \mathrm{H}_{5} \mathrm{Cl} ; \mathrm{CHI}_{3}>\mathrm{CHBr}_{3}>\mathrm{CHCl}_{3}$; $\mathrm{CH}_{2} \mathrm{Br}-\mathrm{CH}_{2} \mathrm{Br}>\mathrm{CH}_{2} \mathrm{Cl}-\mathrm{CH}_{2} \mathrm{Cl}$.

In the polymerization of styrene with $\mathrm{Cr}^{2+}-\mathrm{CHCl}_{3}$ system, the rate of polymerization was found to be proportional to the concentration of styrene and to the square root of the concentration of $\mathrm{Cr}^{2+}$ and $\mathrm{CHCl}_{\text {s }}$ respectively and the apparent activation energy was $11.6 \mathrm{kcal} / \mathrm{mol}$.

From the above results and the results of copolymerization of styrene with methyl methacrylate, it was found that the polymerization of styrene with this initiator system proceeded by radical mechanism and was initiated with alkyl radical formed from the halogen abstracting reaction of $\mathrm{CHCl}_{3}$ with $\mathrm{Cr}^{2+}$.

The $\mathrm{Cr}^{2+}-\mathrm{CHCl}_{3}$ system initiated the polymerizations of styrene and methyl methacrylate, but was ineffective for the polymerization of acrylonitrile and vinyl chloride.

\title{
$m$-アミノフェノール樹脂による気相でのアミン類の吸着 ${ }^{12)}$
}

\author{
(1972 年 7 月 3 日 受 理)
}

橋田勲・鈴江 忠之・西村 正 人* $^{*}$

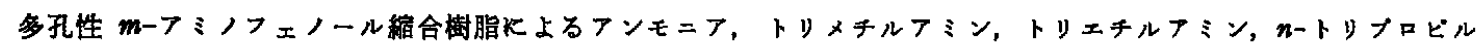
アミンおよびnートリブチルアミンの気相での吸着除去を試み，野的フミン服着能々椡脂の細孔構造との関連性につ き虽討した。気体の流速が $40 \mathrm{~cm} / \mathrm{sec}$ 以下では気体状フミン類は $\mathrm{R}-(\mathrm{OH})\left(\mathrm{NH}_{2} \mathrm{HCl}\right)$ 形の樹脂によって完全に吸着 除去され，破過吸着容量は被吸着気体の分子量，水への溶解度ならび飞流速により影裂されるが，多孔性樹脂の細孔 半径が $1500 \AA$ 以上飞なると影帮は少なくなり，細孔を有しない樹脂では吸着容量はいちしるしく小さい。また， フ ンモニアの静的吸着は Freundlich 型等温吸着式で表示でき，温度侬存性は大きく，微分吸着熱は 5〜6 kcal/mol で ある。

\section{1 楮 言}

多孔性吸着剂に気体が吸着される場合，吸着体の細孔構造（細 孔径や表面積など）が吸着量および速度, 見かけの吸着活性化工 ネルギーに大きな影響をおよ湆すことはよく知られている。す た，活性表面上での物理的，化学的な吸着反応は，一般に，かな り速いために，細孔内での気体の拡散が吸着律速である場合が多 い。細孔内での拡散法分子拡散または Knudsen 抎散にしたがい，

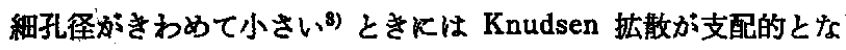
り，その拡散定数 $D_{\mathrm{K}}$ は式（1）で表わされる。

$$
D_{\mathrm{K}}=\frac{2}{3} \vec{r} C=\frac{4}{3} \vec{r}\left(\frac{2 R T}{\pi M}\right)^{1 / 2}
$$

ここで $\bar{r}$ は細孔半径， $C$ は気体の平均速度， $M$ 注分子量, $R$ は

気体定数，T絶対温度.

細孔内での抎散速度を大きくするためには，式（1）より細孔径 をできるだけ大きくする必要がある。

本報では，いろいろな水溶性無機塩の存在下で $m$-アミノフェ

1）この報文を“イオン交換体による気体の吸着（第 4 報）”と する。

2）前報 (第 3 報), I. Hashida, M. Nishimura, J. Polym. Sci. Part A-1，投稿中.

* 大岅市立工菜研究所, 大阪市北区北罣町

3) A. Wheeler, Advan.Catal., 3, 266(1951).
ノール（以下 m-AP と略記する）をホルマリンで縮合させて， 細孔構造の異なる種々の多孔性吸着成2) 合成し,これらの多孔 性 $m$-AP 樹脂化よるアンモニア, トリメチルアミン, トリェチ ルアミンなどの気体状アミンの動的吸着について検討し， $m$-AP 樹脂の細孔構造，とくに細孔径のアミン吸着能に拉よぼす影響を 調べ,さらに, アンモニアの静的吸着について検討したので，そ の結果を報告する。

\section{2 实験}

\section{1 㴻脂の合成}

2.1.1 m-AP 榯绉：m-AP 樹脂は塩化ナトリウム, 塩化カル シウム，硫酸アンモニウムの存在下ですでに報告2)した方法にし たがってアミノフェノールを縮合させ，いろいろな多孔性構造を もったるのを合成した。アミン類の吸着に使用した樹脂の細孔構 造を表 1 に示した。

樹脂の電子顕微鏡写真2) から，多孔性樹脂はゲル状の極微細な 球状粒子（值径 $3 \sim 10 \times 10^{-1} \mu$ ) がたくさんあつまって三次元的 に連ながり合った集合体からできていることが楒められた。

2.1.2 レソルシン樹脂：レゾルシン樹脂は Pennington ${ }^{4)} ら の$ 方法によってつぎのよらに合成した。レゾルシン（試薬一級品）

4) L. D. Pennington, M. B. Williams, Ind. Eng. Chem., 51, 759(1959). 